\title{
A védőoltások szerepe a betegségek megelőzésében: Osztrák Védőoltási Nap (Österreichischer Impftag), 2018
}

\author{
The role of vaccines in the prevention of diseases: \\ Austrian Vaccination's Day (2018)
}

Szerző: Schmidt Péter $\square$

Egyetemi Oktató Gyermekorvosi Rendelö, Györ

Beküldve: 2018. 01. 19.

doi: 10.24365/ef.v59i1.226

\begin{abstract}
Kulcsszavak: kötelező és ajánlott védőoltások, utazási megbetegedések, költség/haszon elemzések az átoltottság során, indikátorok, tudásmegosztás

Keywords: compulsory and recommended vaccinations, travel illnesses, cost/benefit analyses during the vaccination coverage, indicators, knowledge sharing
\end{abstract}

A nagy hagyományokkal rendelkező, évente megrendezett Osztrák (Védő) oltási Napot (Österreichischer Impftag) idén január 13-án tartották az osztrák fővárosban.

A nemzetközi konferencián a résztvevők száma 700 fő felett volt. A hallgatóság sok szakterületet képviselt: többségben orvosok - közülük is főként gyermekorvosok és iskolaorvosok -, továbbá egészségnevelési szakemberek, nagy számban gyógyszerészek, a közegészségügyi higiénés intézetek munkatársai, valamint osztrák- és nemzetközi gyógyszerkutató intézetek vezetői és előadói voltak jelen.

Ausztrián kívül Németországból, Franciaországból, Angliából és Svájcból is érkeztek résztvevők. Magyarországot e sorok írója képviselte, aki egyben az Osztrák Gyermekorvosok Társaságának is rendes tagja.

A konferencia a következő témákat érintette: Mag. Beate Hartinger Klein Miniszter asszony, Egészség- ügyi és Családügyi Minisztérium (Bundesministerium für Gesundheit und Frauen); nagy ívű megnyitó beszédében kiemelte a legfrissebb hazai eredményeket, melyeknek következtében Ausztriában újabb oltóanyagok váltak térítésmentessé. Részletesen ismertette az osztrák oltási séma szerinti kötelező és ajánlott oltásokat. Ausztriában nincsen BCG oltás, de térítésmentesen biztosított a diftéria-szamárköhögés-tetanusz, a járványos gyermekbénulás, a Haemophilus influenzae, a Pneumococcus, a Hepatitis "B” és a kanyaró-rózsahimlo"mumpsz elleni oltások, továbbá a Rotavírus elleni oltóanyag is. Ezen túlmenően serdülő korban a meningococcus ACWY elleni oltás, valamint a Humán Papilloma Vírus (HPV) elleni oltás - nem csak a lányoknak, hanem a fiúknak is - hozzáférhető.'

Prof. Dr. Ursula Wiedermann-Schmidt, Specifikus és Trópusi Megbetegedések Megelőzése Intézet, Bécs (Institut für Spezifische Profylaxe und Tropenme-

' BCG - gümőkór (tbc) ellen, Haemophilus influenzae és Pneumococcus - ezen kórokozók okozta invazív betegségek ellen, Hepatits B - B vírus okozta fertőző májgyulladás ellen, meningococcus ACWY - ezen kórokozók okozta gennyes agyhártyagyulladás ellen 
dizin, Wien); a nemzetközi konferencia szakmai igazgatója elmondta, komoly gondot jelent a migránsok esetében, hogy számos olyan fertőző betegséget hozhatnak be Ausztriába, melyek évtizedek óta eltűntek (pl. járványos gyermekbénulás). Ezért széles körben, mindenre kiterjedő felvilágosító, prevenciós munkát indítottak, hogy növeljék az átoltottságot. E mellett az új oltási rend alapján már 10 hónapos korra előrehozták a kanyaró-rózsahimlő-mumpsz elleni védőoltás beadásának javasolt idejét, hogy minél előbb biztosítsák a védettséget. Gondot az jelenthet, hogy számos szülő nem él a lehetőséggel, hogy gyermekét beoltassa, ezért az átoltottság lényegesen alacsonyabb, mint Európa számos más országában (pl. Magyarországon). Ausztriában az egyik legfontosabb feladat, hogy egészségmegőrző és egészségnevelési programokkal hívják fel a szülők figyelmét a védőoltások fontosságára.

Prof. Dr. Ursula Kunze, Bécsi Orvosi Egyetem, Társadalomorvostani Intézet, Egészségfejlesztési Centrum (Institut für Sozialmedizin, Zentrum für Public Health, Medizinische Universität, Wien); arról számolt be, hogy a kötelező védőoltások mellett az ajánlott oltásokat is támogatja az osztrák állam.
Részleges térítés mellett ajánlott a meningococcus „B" és „C"ii, a bárányhimlő, az influenza, a hepatitis „A" és a kullancs terjesztette agyvelőgyulladás elleni védőoltás. Ez utóbbi igen népszerü. A szülők a gyógyszertárakban megvásárolt vagy az orvosok által felírt oltóanyagot kiváltják, és az oltás beadását követően a Krankenkasse (Betegségbiztosítási Intézet) a kullancsfertőzés elleni védőoltás árának jelentős részét visszatéríti a szülőknek.

Univ.- Prof. Dr. Ingomar Mutz, Tartományi Kórház Leoben/Eisenerz, Stájeroszág; (Landeskrankenhaus, Leoben/Eisenerz, Steiermark) az oltást ellenzők problémakörét illetően hangsúlyozta a szülők felelősségét is, hiszen egy nem beoltott gyermek közösségbe kerülve nagyon sok társát fertőzheti meg. Mind szélesebb körben alkalmazandó egészségnevelési és egészségügyi felvilágosító munka szükséges ahhoz, hogy egyre kevesebb szülő legyen, akik megtagadja gyermeke számára az oltás beadását. Kimutatása szerint évente 3,5 millió védőoltást adnak be Ausztriában, és 30 esetben fordult elő, hogy panaszt tettek súlyos oltási mellékhatások miatt. A vizsgálatok során kiderült, hogy ebből a 30 esetből is mindössze három eset felelt meg a védőoltás okozta kóros elváltozásnak.

\section{1. ábra: Csoportkép az Osztrák Védőoltási Napon}

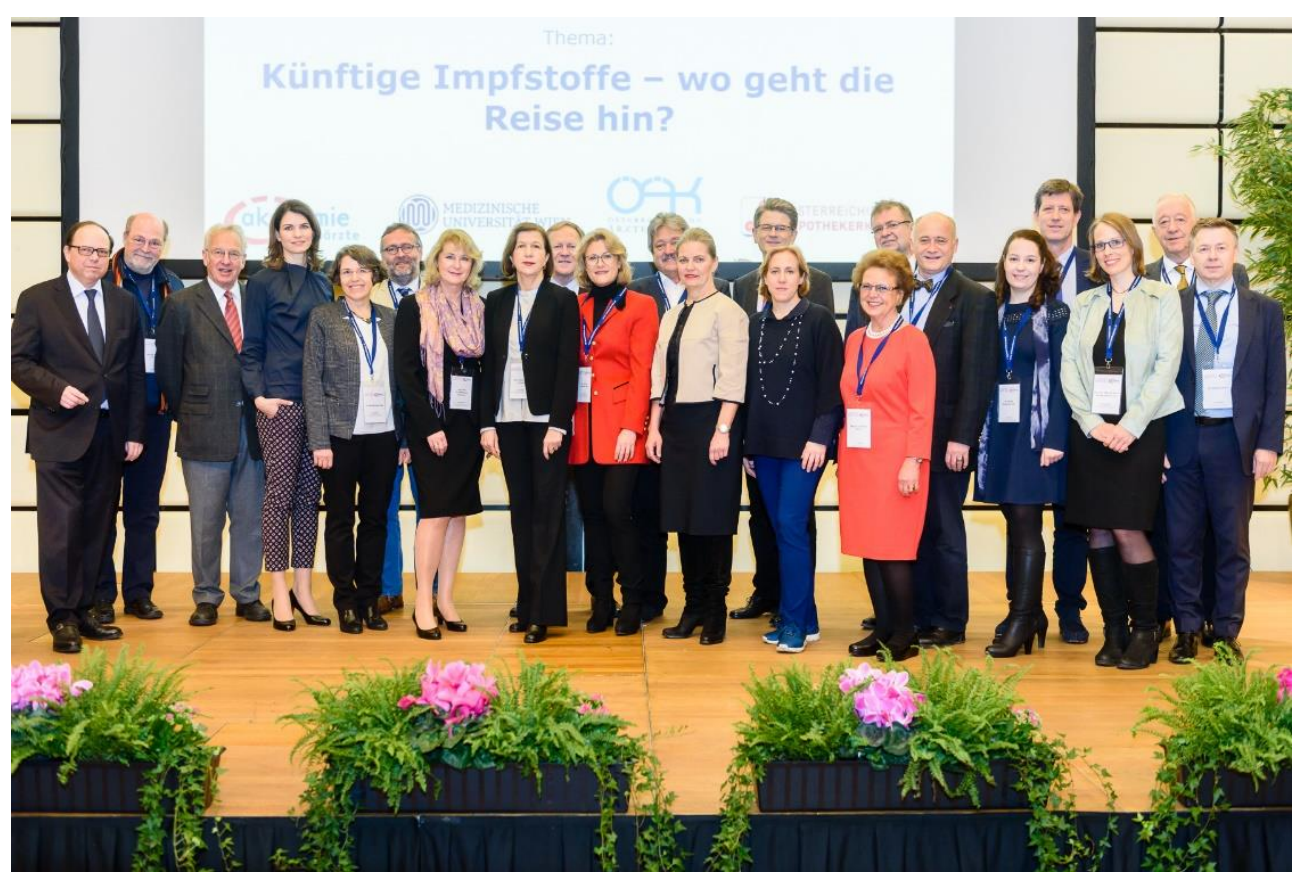

Forrás: Az esemény fotógalérája

\footnotetext{
ii meningococcus B és C okozta gennyes agyhártyagyulladás ellen
} 
Dr. Monika Redlberger-Fritz, Orvosi Egyetem, Virológiai Központ, Bécs (Zentrum Virologie, Medizinische Universität, Wien); véleménye szerint további fontos teendő, hogy Ausztriában mind több ajánlott védőoltás is térítésmentes lehessen. Erre példa lehet az influenza elleni védőoltás - különös tekintettel az influenzajárványok megakadályozására -, hiszen ennek sikeres megvalósítására Ausztriában az anyagi fedezet megvan. Az előadó költség/haszon vizsgálatok eredményeivel igazolta, hogy mind nagyobb mértékú az influenza elleni oltások száma, annak eredményként az influenza okozta megbetegedések időszakában (átlagosan 3-4 hét időtartam) lényegesen kevesebb beteg jelenik meg a rendeléseken. Tehát az influenzaoltások beadása következtében az orvoshoz fordulás aránya jelentősen csökkenhet.

Univ.- Prof. Dr. Hartmut Hengel, Egyetemi Klinika, Virológiai Intézet, Freiburg (Institut Virologie, Universitätsklinikum, Freiburg); Németországban és Franciaországban, valamint Ausztriában végzett kutatómunkája alapján hangsúlyozta, a jól felépített oltási programok mind indirekt, mind direkt módon - a fertőző betegségek megakadályozásával - csökkentik azok kezelésére szolgáló összegeket, a fekvő beteg intézményekbe történő beutalást, ezzel összhangban a kórházban eltöltött napok számát, valamint a szülőknek gyermekük otthoni ápolása miatti munkából való kiesését. Az előadó részletesen beszámolt a 2005-2006-ban megkezdett kutatás eredményeiről, melyek a Herpes-zoster elleni vakcina kidolgozását biztosítják. Elismeréssel szólt japán kutatók vizsgálati eredményeiről a főként az idős korosztály - különös tekintettel a 65 év felettiek - Herpes-zoster elleni védelmét segítő készítmény kifejlesztéséről.

Univ.- Prof. Dr. Robert Steffen, Zürichi Egyetem, Belgyógyászat és Utazási Betegségek és a WHO Együttmúködési Központ igazgatója (FMH für Innere Medizin, Reisemedizin an der Universität Zürich, Schweiz und Direktor des WHO Collaboratoring Zentre for Traveller's); az utazási megbetegedésekkel kapcsolatosan az elmúlt 30 évben végzett gyakorlati tapasztalatairól számolt be. Kronológiai sorrendben kitért a malária megbetegedés, a dengue-láz, illetve a Zika-vírus okozta fertőzések terápiás lehetőségeire, illetve ezen betegségek elleni oltóanyagok kutatására és alkalmazására.

2. ábra: Előadás az Osztrák Védőoltási Nap eseményen

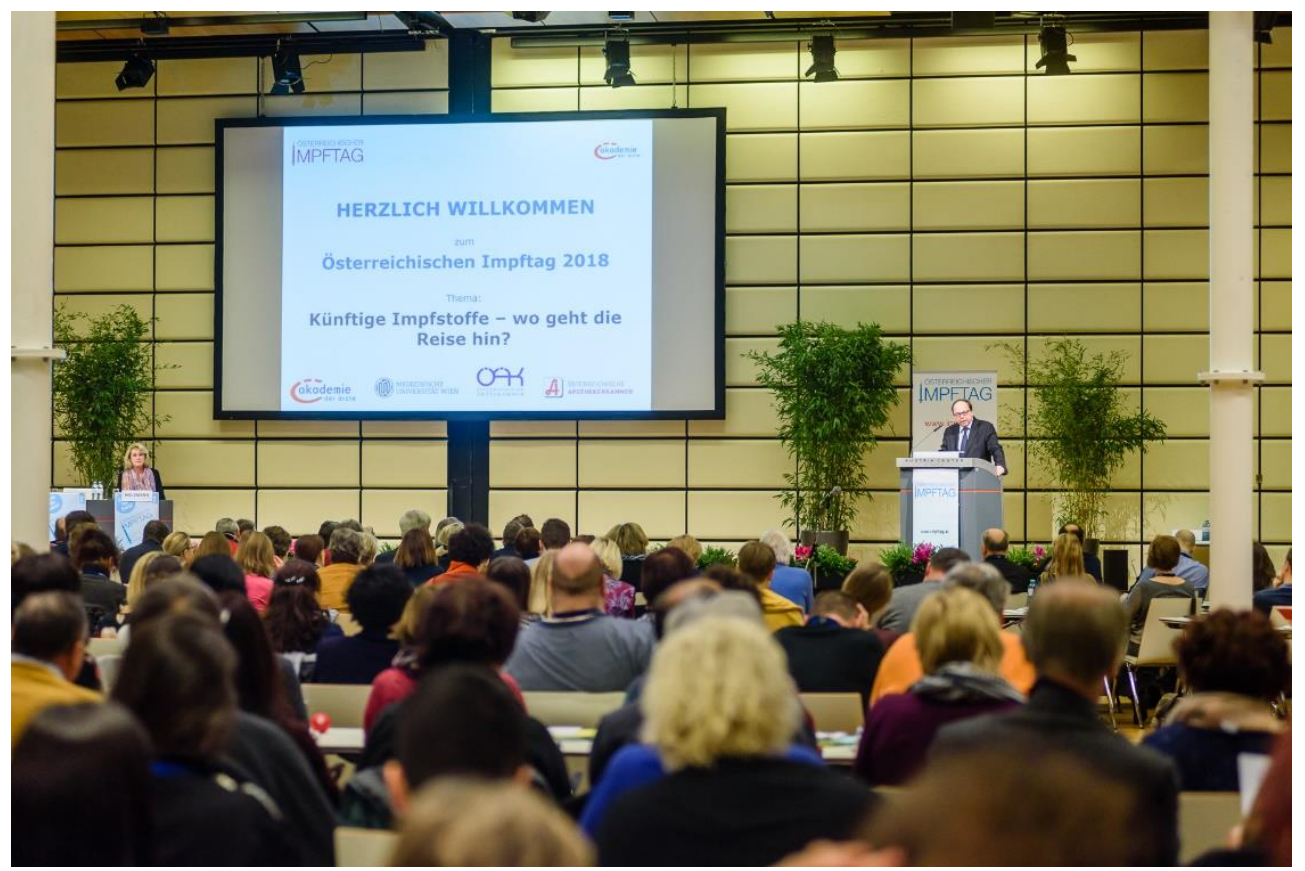

Forrás: Az esemény fotógalérája 
Még mindig több százezres nagyságú az évente maláriában, illetve dengue-lázban elhunytak száma a világban, bár az elmúlt évtizedben mindkét betegség esetében csökkent a mortalitás. A Zika-vírus okozta megbetegedésekkel kapcsolatosan a kutatások jelenleg is folynak, a 2017-ben elsőként alkalmazott oltóanyag alkalmazásától a kutatók kedvező eredményeket várnak. Az eddigi visszajelzések egy hatékony terápia adatairól tanúskodnak. Az utazási megbetegedésekkel kapcsolatban az előadó kitért arra is, a fejlett nyugati országokban folyamatosan felhívják a fiatal házasok figyelmét arra, hogy amennyiben lehetséges - ne tervezzenek nászutat olyan távoli országokba, mind például Egyiptom, vagy a Távol-Kelet, Dél-Amerika egyes veszélyeztetett országai (pl. Brazília, Chile), ahol a fent említett fertőző betegségek aránya még mindig nagyon magas. Ugyanis egy fertőzött szúnyog csípése is végzetes lehet a családalapítást illetően, mivel magzati károsodást, értelmi képességek zavarával járó, kóros kisfejúséget (microcephalia) okoz.

Prof. Dr. Schmidt Péter, jelen beszámoló szerzője előadásában részletesen kitért a magyarországi védőoltással kapcsolatos indikátorokra. Ismertette: Magyarországon igen magas a kötelező védőoltások átoltottsága, az ausztriai 68-70\%-kal szemben hazánkban közel 97-99\%-os. Mindez köszönhető a kiváló magyar - évtizedek óta hatékonyan és precíz nyilvántartással múködő - oltási rendszernek. iii A kötelező gyermekkori védőoltások - állami támogatással - ingyenesek. Az ajánlott oltások ára Magyarországon a családi jövedelmekhez viszonyítva egyelőre aránytalanul magas, de 2016 óta komoly törekvések vannak arra nézve, hogy mind több ajánlott oltás is térítésmentes legyen, vagy legalábbis kedvezménnyel lehessen azokat kiváltani. Ugyancsak komoly eredmény, és hatékonyan múködik az általános iskolákban egyes meghatározott korcsoportokban térítésmentesen adható Hepatitis „B" elleni oltás, továbbá a HPV elleni oltás lányok számára, ugyanakkor fontos cél lehet ezen oltás támogatottságának a kiterjesztése a fiúk számára is. A bécsi konferencia kiemelkedő módon megfelelt a tudásmegosztás nemzetközi követelményeinek.
A tudományos előadásokat követően a résztvevők okostelefonjaik segítségével tesztvizsgát tettek. Az egyes kérdések felvetítése után megtárgyalták az előadások anyagát, majd 4-5 tesztkérdés közül kellett kiválasztani a helyes választ, melyet komoly szakmai konzultáció követett. Előfordult ugyanis, hogy egyes kérdéseknél akár több helyes megoldást is elfogadtak, így a vitafórum hasznos konszenzussal zárult.

\section{Összefoglaló}

A kiválóan megszervezett 2018. évi Osztrák Oltási Nap tudományos szimpóziumán a résztvevők naprakész információt kaphattak a legújabb oltási rendszerekről. A magas szintű szakmai előadások anyagát elsajátítva a kollégák napi munkájukban eredményesen tudják alkalmazni és felhasználni az elmondottakat.

\section{Köszönetnyilvánítás}

$\mathrm{Az}$ "Österreichischer Impftag 2018. Wien” nemzetközi konferencián való részvételemért és az előadásra történő felkérésért hálás köszönettel tartozom az Osztrák Gyermekorvosok Társaságának, (Östrreichische Gesellschaft für Kinder- und Jugendheilkunde), és külön a szervezet elnökének, Dr. Wolfgang Sperl professzornak (Salzburg) a hivatalos bécsi meghívásért, valamint Michael Kunze professzornak, Bécsi Orvosi Egyetem, Társadalomorvostani Intézet, Egészségfejlesztési Centrum Institut für Sozialmedizin, Zentrum für Public Health, Medizinische Universität, Wien); aki már közel 20 év óta biztosít számomra szakmai együttmúködést osztrák egészségügyi intézményekkel (Osztrák Szövetségi Egészségügyi Intézet, Bécs (Österreichische Bundesinstitut für Gesundheitswesen, Wien); a Bécsi Orvostudományi Egyetem (Medizinische Universität, Wien). A szervezésben való kimagasló munkáért - az előző évekhez hasonlóan - Mag. Margot Tschank asszonynak, az Osztrák Védőoltási Nap (Österreichischer Impftag) 2018 szervezési bizottság munkatársának tartozom hálás köszönettel.

\footnotetext{
iii Magyarországon a kötelező védőoltásokat a 18/1998.(VI.3) NM rendelet 5.§. határozza meg. A védőoltási tevékenységgel kapcsolatos információkat, beleértve az ajánlott oltásokat is az évente kiadott Módszertani Levél tartalmazza. Az utolsó (2017. évi) elérhetősége: https://www.antsz.hu/data/cms83440/VML2017 EMMI.pdf
} 


\section{AJÁNLOTT TOVÁBBI IRODALOM}

- Boda Domokos - Bartyik Katalin - Szüts Péter - Turi Sándor: Varicella elleni aktív védőoltások subcutan és intracutan alkalmazott gyengített élővírus vakcinával kórházi fertőzéseknek kitett gyermekeken. ORVOSI HETILAP, 126, 1985

- Budai József - Nyerges Gábor: Védőoltások. Medicina Könyvkiadó, Budapest, 2004

- Budai József: Fontos változások a gyermekek kötelező, korhoz kötött védőoltásaiban. HIPPOCRATES, VIII/1. 2006. január-február, 36.

- Mészner Zsófia (szerk.): Felnőttkori védőoltások kézikönyve - Gyakorlati útmutató orvosoknak. Medicina Könyvkiadó, 2015

- Schmidt P. Minőségi indikátorok szerepe a hazai védőoltási rendszer elmúlt negyedszázados történetében - GAZDASÁG ÉS TÁRSADALOM (2) pp. 7-33. (2005)

- Schmidt P. Az egészségmegőrzés és egészségnevelés kiemelt szerepe a hazai korszerűsített védőoltási rendszerben. EGÉSZSÉGFEJLESZTÉS 47:(1-2) pp. 38-49. (2006)

- Schmidt P. Terhesség alatt pertussis ellen oltott anyák koraszülöttjeinek pertussisellenes antitesttiterkoncentrációja. ORVOSI HETILAP 158:(17) p. 679. (2017) 